\title{
Review \\ Novel Green Approaches for the Preparation of Gold Nanoparticles and Their Promising Potential in Oncology
}

\author{
Tanima Bhattacharya ${ }^{1,2, *(\mathbb{D}}$, Debashrita Das ${ }^{3,4}$, Giselle A. Borges e Soares ${ }^{5}\left(\mathbb{0}\right.$, Prasun Chakrabarti ${ }^{2}$, \\ Zhaoquan Ai ${ }^{1}$, Hitesh Chopra ${ }^{6}{ }^{(\mathbb{C}}$, Madalin Alexandru Hasan ${ }^{7}$ and Simona Cavalu ${ }^{7, *}$ (])
}

\section{check for}

updates

Citation: Bhattacharya, T.; Das, D.; Borges e Soares, G.A.; Chakrabarti, P.; Ai, Z.; Chopra, H.; Hasan, M.A.; Cavalu, S. Novel Green Approaches for the Preparation of Gold Nanoparticles and Their Promising Potential in Oncology. Processes 2022, 10, 426. https://doi.org/10.3390/ pr10020426

Academic Editors: Vilma Petrikaite and Christian Celia

Received: 12 January 2022

Accepted: 18 February 2022

Published: 21 February 2022

Publisher's Note: MDPI stays neutral with regard to jurisdictional claims in published maps and institutional affiliations.

Copyright: (C) 2022 by the authors. Licensee MDPI, Basel, Switzerland. This article is an open access article distributed under the terms and conditions of the Creative Commons Attribution (CC BY) license (https:// creativecommons.org/licenses/by/ $4.0 /$ )
1 Hubei Collaborative Innovation Centre for Advanced Organic Chemical Materials, Hubei University, Wuhan 430062, China; aiz-q@sohu.com

2 Innovation, Incubation \& Industry (I-Cube) Laboratory, Techno India NJR Institute of Technology, Udaipur 313003, Rajasthan, India; prasun.chakrabarti@technonjr.org

3 School Of Community Science \& Technology IIEST Shibpur, Howrah 711103, West Bengal, India; debashritadas95@gmail.com

$4 \quad$ PRCS Technologies 94, Phears Lane, Kolkata 700012, West Bengal, India

5 Department of Medicinal and Biological Chemistry, University of Toledo, 3000 Arlington Ave., Toledo, OH 43614, USA; giselleamanda.borgesesoares@rockets.utoledo.edu

6 Chitkara College of Pharmacy, Chitkara University, Rajpura 140401, Punjab, India; hitesh1704.ps.phd@chitkara.edu.in

7 Faculty of Medicine and Pharmacy, University of Oradea, P-ta 1 Decembrie 10, 410087 Oradea, Romania; hasan.alexandru@didactic.uoradea.ro

* Correspondence: btanima1987@gmail.com (T.B.); scavalu@uoradea.ro (S.C.)

\begin{abstract}
The difficulty of achieving targeted drug delivery following administration of currently marketed anticancer therapeutics is a still a concern. Metallic nanoparticles (NPs) developed through nanotechnology breakthroughs appear to be promising in this regard. Research studies pertaining to gold NPs have indicated their promising applicability in cancer diagnosis, drug delivery and therapy. These NPs have also recently paved the path for precise drug delivery and site-specific targeting. Our review paper thus highlights the scope and impact of biogenetically generated gold nanoparticles (NPs) in cancer therapy. In a critical, constructive, and methodical manner, we compare the advantages offered by gold NPs over other metal NPs. Moreover, we also focus on novel 'greener' strategies that have been recently explored for the preparation of gold NPs and shed light on the disadvantages of conventional NP synthesis routes. Future prospects pertaining to the use of gold NPs in oncotherapy and domains that require further investigation are also addressed.
\end{abstract}

Keywords: gold nanoparticles; biogenetic; pathway; nanomedicines; cancer treatment

\section{Introduction}

Gold particles having dimensions ranging from 1 to $100 \mathrm{~nm}$ are referred to as gold nanoparticles (NPs) while their dispersion in an aqueous phase is referred to as 'colloidal gold particles' [1]. These NPs offer several advantages such as superior biocompatibility, excellent optoelectronic features, huge surface to volume ratio and lower toxicity in comparison to other NPs. Moreover, their large surface area and unique surface modification capability makes them excellent drug carriers. These NPs have also been investigated for their ability to detect biomolecules, for induction of tumor cell apoptosis through hyperthermia, and for labelling of proteins, cells, etc. It is, therefore, no surprise that from a global standpoint, exploration of the biomedical applications of gold NPs is a significant ongoing research domain.

Cancer has been recognized as one of the leading causes of death and is characterized by the rapid growth of abnormal cells that have an uncontrollable rate of division, along with the capability of infiltration and destruction of normal tissues in the body. Cancer can spread throughout organs in the body that differ from its primary site of origin, and 
is mainly caused through DNA (deoxyribose nucleic acid) mutations that occur intracellularly [2,3]. Errors in genetic transcription or translation affect cellular function and performance, thus causing cells to become cancerous [4-8]. Due to its widespread nature and huge mortality rate, it is of utmost importance to focus on treatment strategies that can help minimize the formation and progression of carcinomas [9-13].

Photothermal therapy using gold NPs may assist with this challenge due to its photon absorbing capability, ultimately transforming NPs into heat, thereby destroying cancer cells [14]. Carcinogenic cells over-express cell receptors on their surface [15]. Therefore, gold NPs targeting these receptors can help eliminate tumor cells [16]. Moreover, gold NPs also have the capability of generating reactive oxygen species (ROS) that can further assist in killing tumor cells [17]. It is these properties of gold NPs that make them promising candidates for the diagnosis and treatment of carcinomas [18,19].

Our current review provides readers with an understanding of the various routes of gold NPs and their use as anticancer agents [20-24].

\section{Green Synthesis Techniques for Preparation of Gold NPs}

The use of NPs has found great application in biology. As a result, currently, the study of novel efficient methods for the preparation of metal NPs is still underway [25-29]. The conventional preparation of gold NPs involves either a (1) physical, (2) chemical, or (3) biosynthesis method. However, these techniques have both advantages and disadvantages, as described in Table 1.

Table 1. Advantages and disadvantages of chemical and bio-synthetically prepared gold NPs.

\begin{tabular}{|c|c|c|c|}
\hline Method & Advantage & Disadvantage & Ref. \\
\hline $\begin{array}{l}\text { Chemical } \\
\text { method }\end{array}$ & $\begin{array}{l}\text { Size and morphology } \\
\text { modifications can be } \\
\text { achieved through the } \\
\text { varying the volume of } \\
\text { organic solvents and } \\
\text { reagents used in the } \\
\text { preparatory process. }\end{array}$ & $\begin{array}{l}\text { Cost of reagents is high. } \\
\text { Process involves the use of } \\
\text { agents such as stabilizers } \\
\text { and reducers thar are toxic } \\
\text { and biomedically harmful. }\end{array}$ & [30] \\
\hline $\begin{array}{l}\text { Bio-synthesis } \\
\text { method }\end{array}$ & $\begin{array}{l}\text { - Aggregation and stability } \\
\text { can be modified through } \\
\text { NP capping using } \\
\text { bio-reagents. }\end{array}$ & $\begin{array}{l}\text { Toxicity aspect requires } \\
\text { consideration as this } \\
\text { method is still being } \\
\text { explored. } \\
\text { Mechanistic and kinetic } \\
\text { aspects pertaining to NP } \\
\text { preparation need to be } \\
\text { looked into. } \\
\text { Difficult to control size and } \\
\text { shape of NPs. } \\
\text { Large-scale preparation of } \\
\text { NPs using this method is } \\
\text { not feasible. }\end{array}$ & {$[31,32]$} \\
\hline
\end{tabular}

Novel methods of green route synthesis of gold nanoparticles are currently being studied and investigated [33,34]. Green synthesis offers the benefits of being non-toxic and eco-friendly, while being highly cost effective. It employs the use of sunlight, irradiation, and microorganisms such as fungi, algae, and bacteria for the preparation of NPs used both intracellularly and extracellularly [35]. Various types of gold NPs, such as gold nanospheres, nanorods and nanostars, can be prepared using this technique. Lee et al. found that on HepG2 (human hepatocyte carcinoma) cells, the gold nanospheres showed a cytotoxic effect, followed by gold nanorods and nanostars. [36]. 
In addition to utilizing microorganisms, gold NPs can also be developed using plant extracts, such as leaves [37-41] roots, flowers, seeds, and bark. The extract is then subjected to centrifugation and filtration to obtain NPs from specific metal ions [42,43], as illustrated in Figure 1.

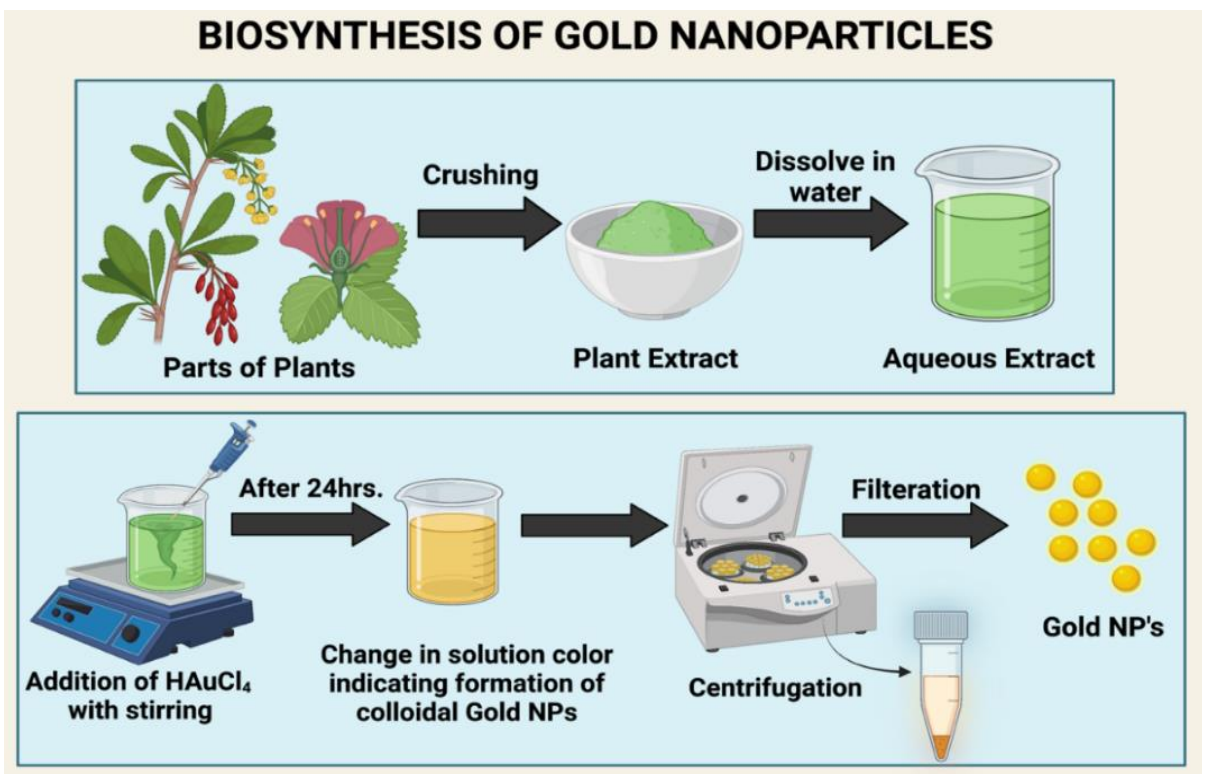

Figure 1. Illustration of the laboratory synthesis of gold NPs using plant extracts (created using Biorender.com, accessed on 10 January 2022).

As Lee et al. found in 2020, the process of making gold nanoparticles is very dependent on green materials such as enzymes, bacteria, plants, and fungi [44]. Table 2 provides a summary of some of these agents and the processes involved for the synthesis of gold NPs. Gold NPs produced through these means were found to be promising as phytomedicines and natural formulations of various ailments for multiple applications [45].

Table 2. Summary of the natural products and the processes involved in the preparation of gold NPs.

\begin{tabular}{|c|c|c|}
\hline Method & Process & Reference \\
\hline $\begin{array}{c}\text { Green Chemical } \\
\text { Method }\end{array}$ & $\begin{array}{l}\text { Green and environmentally friendly chemicals such as } \\
\text { starch, chitosan, glucose are used either as capping or } \\
\text { reducing agents, or even both. Polymers such as carboxy } \\
\text { methyl cellulose and polyethylene glycol are also used to } \\
\text { produce gold NPs. }\end{array}$ & {$[46,47]$} \\
\hline $\begin{array}{c}\text { Plant Extract Based } \\
\text { Method }\end{array}$ & $\begin{array}{l}\text { Extract is prepared using fruits, peels, roots, leaves and } \\
\text { other plant parts, which behave as the capping and } \\
\text { reducing agent required for metallic ion reduction. }\end{array}$ & [48] \\
\hline $\begin{array}{l}\text { Micro-organism } \\
\text { Based Method }\end{array}$ & $\begin{array}{l}\text { Algae, bacteria, fungi, etc., are grown in culture medium } \\
\text { where the release of capping and reducing agents takes } \\
\text { place in the medium or in biomass. Gold ions are then } \\
\text { added to the medium in controlled environment conditions } \\
\text { to create gold NPs. }\end{array}$ & {$[49,50]$} \\
\hline $\begin{array}{c}\text { Intracellular } \\
\text { Synthesis by Plants }\end{array}$ & $\begin{array}{l}\text { A culture medium containing a high quantity of metal ions } \\
\text { is used for plant growth. The NPs are then formed through } \\
\text { the reduction of metallic ions in the agar medium, which is } \\
\text { then transferred to the plant. However, the NPs are } \\
\text { produced in the biomass, which is a drawback as the } \\
\text { separation of NPs from the biomass is still a huge challenge. }\end{array}$ & [51] \\
\hline
\end{tabular}


Table 2. Cont.

\begin{tabular}{ccc}
\hline Method & Process & Reference \\
\hline $\begin{array}{c}\text { Honey-mediated } \\
\text { Green Synthesis }\end{array}$ & $\begin{array}{c}\text { Aqueous solution of honey can be used to reduce and cap } \\
\text { substances that can be used in preparation of gold NPs. }\end{array}$ & [52] \\
\hline $\begin{array}{c}\text { Microwave } \\
\text { assisted method }\end{array}$ & $\begin{array}{c}\text { Prepared AuNPs using aqueous extract of Trachyspermum } \\
\text { ammi seeds and chemical treatment with HAuCl4 followed } \\
\text { by exposure to microwave radiations. }\end{array}$ & [15] \\
\hline
\end{tabular}

In 2016, Xin Lee et al. synthesized gold NPs through the reduction of gold metal ions in the aqueous phase that were in contact with the aqueous fruit peel extract of Garcinia mangostana [53]. These NPs showed peak absorption ranging between 540 and $550 \mathrm{~nm}$. Additionally, Rodríguez-León et al. in 2019 found that gold NPs could be prepared from the bark extract of Mimosa tenuiflora, which was further obtained from its bark mixture in water and mixed with ethanol [54]. Keijok et al. in 2019 used the green seeds of Coffee arabica due to its high phenolic content, which was certified from international organizations [55]. It was found that the extract of Coffee arabica behaved as a reducing agent, a functionalizer and a stabilizer that aided in the formation of the gold nanostructures. Botteon et al. in 2021 used Brazilian Red Propolis, a product obtained from bees that possesses antimicrobial, anti-tumor, and antioxidant properties. Gold NPs were prepared from Brazilian Red Propolis extract in various solvents such as ethyl acetate, hexan, and dichloromethane [56]. In another manuscript by Doan et al. in 2020, Litsea cubeba fruit extract along with $\mathrm{HAuCl}_{4}$ was used for synthesizing gold nanoparticles that behaved as a stabilizer and a reducer at the same time [57]. The extract from Ocimum sanctum was used in the manuscript of Lee et al. in 2016 for preparing gold NPs with the help of solvent fractionation in a sequential manner [58]. In addition to this, Camas et al. in 2019 isolated Petrosia ficiformis from marine sources and created gold nanoparticles of the Citricoccus species [59].

\section{Significance of Gold NPs in Biomedicinal Applications}

Gold NPs have various applications, such as in vivo imaging, in vitro assays, delivery of various nucleic acids, delivery of drugs, and in vivo targeting, and are used in clinical trials. The compatibility and ease of conjugation of biomolecules with gold NPs, coupled with their optical features and ability to bring about surface modification, makes them highly unique [60]. Gold NPs are also stable and inert, have a high rate of disparity, and are nontoxic, which makes them ideal candidates for biomedicinal applications. Kohout et al., in their review paper, mentioned two important aspects of gold NPs: (1) intrinsic features of the core of the gold, (2) capability of customization of surface functionality of NPs [61]. The study also mentions the fact that although most research studies indicate the non-toxicity of gold NPs, further research pertaining to their toxicity following usage of capping ligands needs to be explored. This is particularly because certain ligands can be associated with toxic effects that can impart toxicity to the entire NP [62]. In addition to cancer therapy, gold NPs have been found to have applications in biochemical sensing, tagging, DNA labeling, cell imaging, and photo thermal therapy, as illustrated in Figure 2. Gold NPs have also been used to detect the presence of metallic ions, such as those of arsenic, lead, mercury, and copper, through a change in color of the gold NP aggregates.

In the study of Alizadeh and Nazari, recent trends and applications in therapeutic sciences of NPs, such as gold, silver, and platinum, were discussed along with an understanding of the toxicity profile of various NPs. However, studies on the ways in which the gold NPs interact with cells have not been conducted [63]. The mechanism of entry along with compartmentalization in the subcellular areas has also not been studied. However, González-Ballesteros et al. mentioned that change in coatings and charge of surfaces, shape, size, and method of synthesis, are important considerations that govern the level of toxicity of gold NPs [64]. Furthermore, gold NPs are widely employed in biosensor production, due 
to their excellent conductivity, catalytic properties, and large surface area. Gold NPs that have been functionalized with calixarene derivatives, peptides, and crown ethers DNA are mostly used as sensory applications for detecting pyridinium, quaternary ammonium ions, and other amino acids. Using the volt metrics approach, indium tin oxide electrodes and gold NPs can be utilized to estimate hydroquinone and catechol levels. This is most used to identify catechol in tea samples. Furthermore, in memory devices, the coating of gold NPs with a suitable insulator is known to provide great stability. This aids in the removal of the applied field by effectively preventing the accumulation of charges within the device. The key area of interest of scientists, as noted in the previous study, is targeted medication delivery, and this is where the benefits and uses of gold NPs come into focus [65]. Another area of interest is the ability of gold nanoparticles to physiologically image malignant cells in the body. Because of the strong attraction of gold NPs to proteins and thiols, it is vital that they are explored in order to be able to efficiently perform as a system for medication delivery to the desired spot within the body [66].

\section{APPLICATIONS OF GOLD NANOPARTICLES}
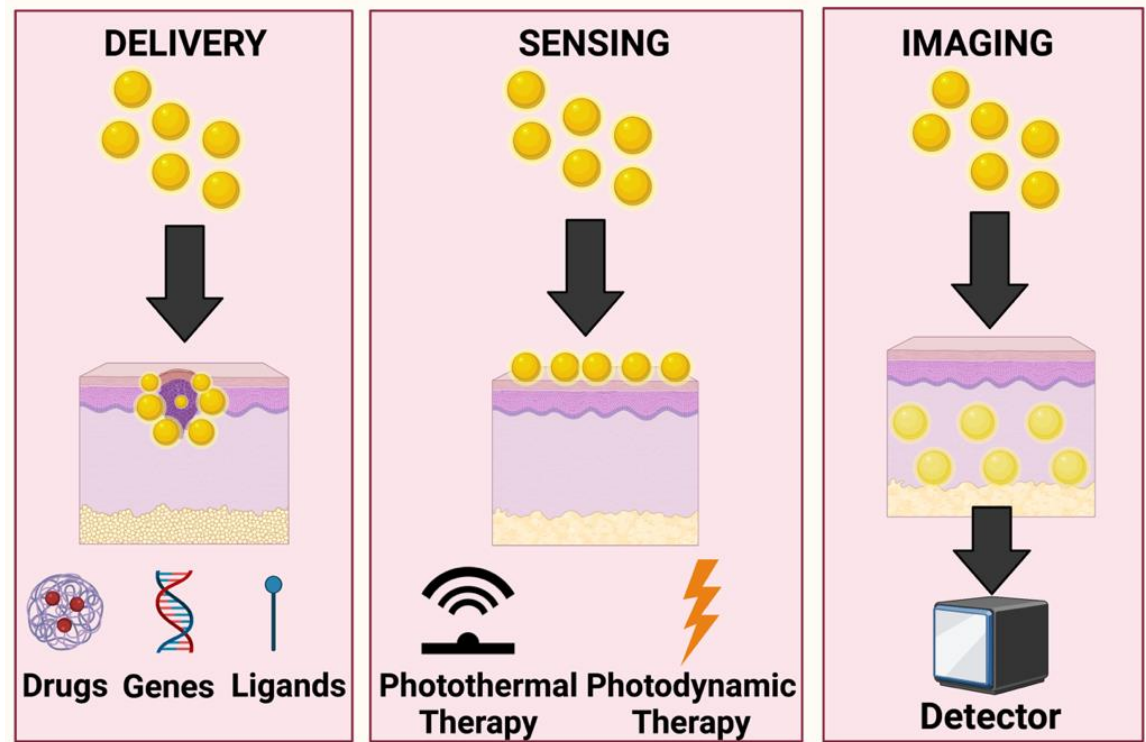

Figure 2. Extent of penetration following administration of gold NPs and their possible biomedicinal applications (created using Biorender.com, accessed on 10 January 2022).

The drug delivery method of gold NPs deserves special mention above that of other NP drug carriers and the currently marketed pharmaceutical products. As shown in Figure 3, gold NPs are usually utilized as an antigen for cancer therapy for treating tumors or malignant cells inside the body. According to Kong et al.'s research, the gold NPs can easily reach the target cells due to their small size and ability to be equally dispersed [67]. Due to their ability to carry a large load of pharmaceuticals and systematically release therapeutic drugs at the surface of target cells via several delivery routes, and an excellent ability to interact with tumor cells, gold NPs are superior to others. The study also claims that conjugating gold NPs with conventional medications can significantly reduce their negative effects, hence improving the patients' quality of life. The use of $5 \mathrm{~nm}$ gold NPs as a vehicle for drug delivery to the target site, and the covalent bond with cetuximab as an active agent for targeting, proved to be an excellent factor in treating pancreatic cancer. Another unique advantage of gold NPs discovered by Khoshnevisan et al. is the capacity to target the tumor site passively via leaky neovessels; that is, the impact of Enhanced Permeability and Retention (EPR) [68]. Furthermore, the paper describes the controlled release of medications that are loaded in response to external and internal stimuli. By utilizing the enhanced buildup of tumor of gold NPs that may be employed for medication delivery, the therapeutic potentiality can be greatly increased while also 
bringing about considerable reductions in negative effects. Similarly, Thambiraj et al. discovered that the higher density of gold NPs allows them to be employed as probing agents in transmission electron microscopy [69]. Gold NPs have been found to aid in the identification of biomarkers that are utilized in the diagnosis and treatment of many types of carcinomas, cardiac disorders, and infection-causing substances. Vines et al. indicated the benefit of gold NPs in terms of photo-dynamic therapy. These particles, following the absorption of IR, are known to produce a significant quantity of heat when activated with lights having wavelengths spanning between 700 and $800 \mathrm{~nm}$ [70]. The targeted tumor cells can thus be eliminated and hence utilized in cancer treatment. When light is irradiated on a tumor that possesses an accumulation of gold NPs internally or on its surface, NPs can readily absorb the heat and become rapidly heated, killing the tumor cells completely. This procedure is known as hyperthermia therapy. Furthermore, gold NPs aid in the development of a suitable platform for the successful delivery of therapeutic genes.

\section{GOLD NANOPARTICLES AS ANTICANCER THERAPEUTICS}

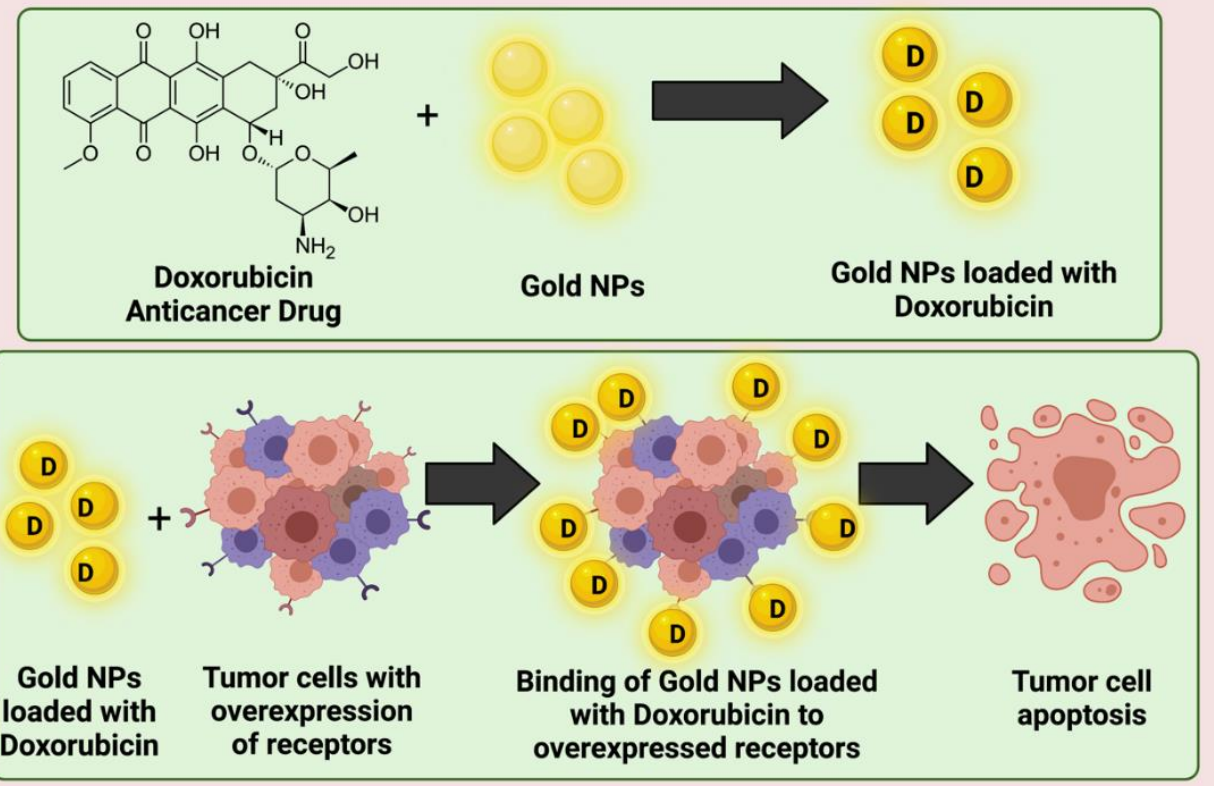

Figure 3. Coupling of anticancer molecules to gold NPs followed by their administration causing tumor cell apoptosis (created using Biorender.com, accessed on 10 January 2022).

In their investigation, $\mathrm{Xu}$ et al. found that gold NPs have the ability to suppress endothelial cell growth both in vitro and in vivo at the site of reduced ascites deposition [71]. Gold NPs were found to interact with and inhibit the heparin binding domain and growth factors such as bFGF (basic fibroblast growth factor) and VEGF-165 (vascular endothelial growth factor-165). Moreover, it was observed that these NPs did not affect epidermal growth factor and VEGF-121. The study indicated the use of these NPs to cause a decline in angiogenesis and edema formation. Proliferation of myeloma has also been restrained with the help of treatment of gold NPs. In this manner, gold NPs show promising application in carcinoma treatment without causing any such toxic effect in the body [71].

\section{Type of Cancer Mainly Treated with Gold Nanoparticles}

There are a variety of diseases that can be successfully treated using gold NP drug delivery; however, the majority of research shows that gold NPs are effective in treating breast cancer [72]. Breast cancer therapy using gold NPs that have been irradiated with a nanosecond short pulse laser was studied by Ojha and Goel [73]. They confirmed the damage of breast cancer cells following usage of nano photolysis. This research is particularly useful because it has effectively demonstrated a method of nanophotolysis 
that selectively kills breast cancer cells. The findings of this research can be applied in future in animal and human clinical trials. The study of Torre et al. by comparison, mentioned another method of using gold nanoparticles in the therapy of breast cancer, namely, laser-induced hyperthermia, because gold nanoparticles can aid in the production of hyperthermia via plasmon resonance with the NIR (Near Infrared) laser [74]. The research study clearly shows that gold NPs have potential properties for not only the therapy of breast cancer, but also for the successful imaging of the disease. This study was able to successfully identify the difficulties of directly introducing gold NPs for clinical applications, as there are issues with lack of clearance and a specific tumor cell targeted by the gold NPs. Several studies on the applicability of gold nanoparticles in cancer therapy have been undertaken in order to fully comprehend their impact and significance in cancer treatment.

The mediators that are commonly used in traditional cancer chemotherapy are mostly commonly small molecules that have the potential to harm other healthy tissues in the body due to their non-specific distribution. Furthermore, numerous resistance mechanisms found in cancer cells may occasionally impede the function of those mediators. However, it has been discovered that, to overcome these obstacles in cancer treatment, the usage of gold NPs can be highly useful and effective, as the gold NPs can be properly functionalized utilizing various types of conjugating agents. In this regard, gold NPs having a size ranging from 135 to $160 \mathrm{~nm}$ have been highly investigated. Moreover, they can be manufactured as gold nano-shells that have a branching character, with proven benefits in cancer therapy [75]. Another study reported the utilization of an ice-cold solution of $\mathrm{NaBH} 4$ that rendered gold NPs with a core size of $3.3 \mathrm{~nm}$ coupled with high water dispersibility, and that were captured inside a multifunctional dendrimer conjugated with $\alpha$-tocopheryl succinate [76]. These NPs were found to be an efficient and effective platform for cancer therapy and targeted imaging of cancerous cells. By comparison, a previous study provided another approach for creating hybrid gold nanocomposites having a size of $180 \mathrm{~nm}$ and a spectrophotometer peak at $520 \mathrm{~nm}$ through the deposition of gold on poly lactide co-glycolide loaded with docetaxel [77]. This was discovered to be particularly effective in the treatment of cancer, via both chemo and photothermal therapy, because it may target only tumor cells inside the body. According to this study, the solvent casting process can be used to conjugate micelles and transferrin for the synthesis of gold NPs, which can be employed as a cancer cell imaging agent, theranostic, and a therapeutic agent for cancer treatment [78]. However, the authors of this study did not disclose the spectrophotometer reading at which gold NPs can show their maximum peak. Another study finding indicates that gold NPs can be employed as an effective carrier of several anticancer medications, enhancing therapeutic activity and assisting in the formation of a platform for cancer diagnostics [79].

The application and usage of gold NPs as chemotherapeutic agents in the treatment of cancer has grown quickly, with chemo-radiotherapy being the most popular and highly effective treatment modality in clinics for the successful treatment of many forms of cancer [80]. Nejati et al. [81] discussed the use of gold NPs in a range of biomedical domains, including bioimaging, biosensing, and drug delivery for cancer treatment. In this regard, recent studies or research concerning the use of gold NPs for chemotherapy and radiotherapy are listed in Table 2 . However, there are a limited number of research works on the applications and use of gold NPs in combination with cancer-fighting medicines and radiation therapy. The studies summarized in Table 2, however, show an improvement in the trend of dose response to tumor cells, and a significant reduction in the toxicity of normal tissues in the body. Nonetheless, this requires further investigation before its application in clinics for practical usage. Furthermore, Sathiyaraj et al. describe the use of pan-chagavya, an organic manure, for the manufacture of gold nanoparticles that demonstrated great antibacterial activity against Gram-negative bacteria and moderate activity against Gram-positive bacteria in their investigation [82]. 
In contrast to the findings of these investigations, another study from the Icahn School of Medicine found that gold NPs are more successful in treating prostate cancer than all other types of malignancy. Gold NPs, which are biocompatible and convert near-IR light to heat, are known to be the most effective and safe way to ablate intermediate-grade prostate cancers. In comparison to treatment of the entire gland, such as prostatectomies, the treatment of prostate cancer with gold NPs can be performed in a more effective and targeted manner. This aids in keeping the critical structures present inside the prostate gland intact without any chances of changes or destruction, thereby avoiding the side effects associated with treatments such as prostatectomies. However, this study failed to examine the actual effectiveness of gold NP therapy for prostate cancer. Previous reports nonetheless provide data on the treatment's effectiveness, which were cross-checked with 16 samples with low or intermediate prostate cancer risks [83]. Another advantage of gold NP therapy for prostate cancer discovered in this study was that combining magnetic resonance ultrasound fusion imaging with gold NP therapy for cancer resulted in a substantially longer period of remission. By comparison, according to Li and Lane's research, the popularity of gold NPs in the treatment of prostate cancer is due to two key reasons: early diagnosis and drug delivery to the targeted area [84]. This article also provides data on the clinical and promising applications of gold NPs for the treatment and diagnosis of prostate cancer. Unfortunately, however, none of these studies mentioned the size of gold NPs, which would be beneficial in providing better bioavailability and targeting of prostate cancerous cells. As demonstrated by Luo et al., gold NPs can be classified into three different sizes for the assessment of their individual performance in the treatment of prostate cancer [85]. Another study reports the use of gold NPs that target PSMA (prostatespecific membrane antigen) as promising radio sensitizers that can aid in the treatment of prostate cancer with radiotherapy The significance of the gold NP's size in terms of its ability to sensitize tumor cells to radiation therapy was effectively stated in this paper, the data for which were not found in earlier studies [86].

Furthermore, evidence from various studies that the gold NP can perform the delivery of both water-soluble [87] and water-insoluble drugs [88] to the target site again makes it an attractive metallic NP for the delivery of the desirable drug. According to Dykman and Khlebtsov's research, gold NPs can be loaded with water insoluble medication, such as paclitaxel, using covalent or non-covalent bonding [89]. Because the gold NPs are triggered by phosphodiesterase, which is found in cancer cells, the medication is released in the cancer cells without any drug being released in the serum. To investigate the role of paclitaxel's solubility, studies in which the surface of gold NPs was conjugated with paclitaxel-oligonucleotides-thiol were performed [90]. In this case, an enhancement of the cytotoxic nature of paclitaxel in the sensitive and resistant cells was observed. Gharatape and Salehi's study, by comparison, found that encapsulating a drug with non-covalent bonds aids in the direct release of drug molecules in an unaltered state, and that all of these systems of direct drug delivery can be used as better agents for passively targeting cells due to the EPR effect [91]. It was also shown that water-soluble gold NPs are employed more frequently than insoluble gold NPs, and that their structure is like that of micelles, which are made up of only one molecule, such as dendrimers, that has a hydrophilic exterior and a hydrophobic core. The ligands that are radially arranged are conjugated with the monolayer of the NP containing the alkane thiol that produces hydrophobic pockets inside the monolayer of the NPs [92]. However, the actual effects and success of the medication delivery system could not be fully comprehended from this study because the practical uses of these pockets and their effects were not specified. By comparison, the use of these hydrophobic pockets for drug encapsulation and effective and efficient drug release into cancer cells was mentioned in another study [93]. The features of gold NPs conjugated with doxorubicin, which is water soluble in nature, were noted by Lee et al. and the conjugated NPs also demonstrated a drug release profile that was responsive to the $\mathrm{pH}$ of the system to a large extent [94]. Hydrazone bonds were formed between the molecules of doxorubicin and the methyl thioglycolate segments [95]. The methoxyl polyethylene 
glycols conjugated with gold NPs were discovered to be responsible for the high stability and outstanding solubility in the aqueous medium, and to have the potential to extend circulation time. Another study by Khutale and Casey described a single and unique procedure that may be used to efficiently synthesis stable gold NPs that are loaded with a mixture of two water-soluble anticancer medicines, bleomycin and doxorubicin [96]. This study is noteworthy because it provides a better understanding of the breadth and prospects for additional research into combination chemotherapy that is assisted by gold NPs and uses two medications with optimal and effective concentration. The combined and conjugated medications can function through a variety of ways, reducing the odds of cancer drug resistance, reducing the toxicity and side effects of systemic pharmaceuticals, and improving the overall results and impact of chemotherapy for cancer treatment. Yang et al. discovered that researchers were attempting and eventually developing a methodology for the manufacture of plasmatic gold NPs within cancer cells, thus completely eliminating the need for traditional benchtop methods in laboratories [97]. It was also discovered that the biosynthesized gold NPs had the potential to greatly broaden the traditional biomedical applications of gold NPs. This research is important because it explains how the uncertainties of variations in the functionality, morphology, and size of gold NPs can be completely avoided, and how the biosynthetic method can be carried out directly in the nucleus of human cells in a matter of minutes without the use of any conventional laboratory methods. According to the overall review of studies, because the majority of studies have been based on the delivery of water-insoluble anticancer drugs to target sites using gold NPs, more research is needed to understand and prepare mechanisms for the delivery of water-soluble anticancer drugs in the body.

\section{Pre-Clinical and Clinical Studies of Gold Nanoparticles in Treating Carcinoma}

To determine whether a medicine is suitable for clinical trials and/or pre-clinical investigations, substantial research is required that can aid in acquiring all relevant information on the drug's toxicity, efficacy, safety, and pharmacokinetics. According to the previous studies [98,99], there are few technologies that have been approved by the Food and Drug Administration (FDA) involving gold NPs that are used in diagnosis and therapeutic treatment, and there are few clinical trials that are actively being conducted so that gold NPs can be approved for the treatment and diagnosis of cancer [100]. Understanding and influencing the level of toxicity of gold nanoparticles is largely dependent on the production technique and environment, in addition to the morphology and size of the gold nanoparticles. Although a large amount of information was obtained with Astra Zeneca's and Cytimmune's clinical studies using Aurimune, where they utilized a drug carrier for tumor targeting, the data do not provide any information pertaining to the negative effects of these gold NPs on the human body [101]. In contrast, a number of studies have been undertaken by researchers to determine the cytotoxicity, biodistribution, and physiological response of gold NPs [102]. According to current research, there is a significant gap in understanding the true impact of NPs because, to date, only incongruent and contradictory information is available. As a result, it is critical to investigate the actual impact of gold NPs on human health because there is a possibility of detrimental consequences occurring following the unmonitored administration of these NPs. Another study correctly noted that there are still gaps in our understanding of the overall clinical impact on the human body of gold NPs employed for diagnostics or treatment [103]. A study of CYT-6091, comprising gold NPs coated with citrate, having a diameter of $27 \mathrm{~nm}$, and conjugated with thiolated PEG and tumor necrosis factor $\alpha$ (TNF $\alpha$ ), was the first study of gold NPs that progressed to the early stages of clinical testing. TNF- $\alpha$ was found to possess a dose-limiting hazardous characteristic and produced side effects such as nausea and hypotension in prior research; as a result, it could not be widely employed in clinical procedures. The study also indicated that TNF- $\alpha$ conjugated with gold NPs was able to exhibit a dual impact on enhanced targeting of the tumor along with toxicity of the tumor cells. Another recent study compared the effects of free TNF- $\alpha$ and the combination of gold NPs coated with citrate 
TNF- $\alpha$ complex. The results showed that the combination with gold NPs decreased the toxicity related to TNF- $\alpha$. This study also specified that the toxicity observed with TNF- $\alpha$ was pertinent to both in vivo and in vitro systems. The various research and pre-clinical studies regarding the efficacy of gold NP conjugates in treating various types and forms of cancer are shown in Table 3. The listed research indicates that more pre-clinical and clinical studies based on the effectiveness and efficacy of gold NPs in the therapeutic treatment of cancer should be conducted so that a comprehensive, composite, and better understanding of the matter can be achieved. This will be very useful in future research studies, and identical results and effects from multiple trials without conflicts would undoubtedly aid in the acceptance of gold NPs for targeted therapy in clinical practices [104]. However, with respect to nanomedicine-based research, the most significant challenge is that the in vitro and in vivo data do not correlate. The lack of transparency and clarity surrounding the results of in vitro and in vivo studies is also a serious concern.

Table 3. Current implementation of anticancer medicines conjugated with gold NPs for the delivery of drugs coupled with radiation therapy.

\begin{tabular}{|c|c|c|c|c|c|}
\hline Authors & $\begin{array}{l}\text { Complex of } \\
\text { Nanoparticles }\end{array}$ & $\begin{array}{c}\text { Parameter of } \\
\text { Treatment }\end{array}$ & Modality & $\begin{array}{l}\text { Results from } \\
\text { Experiment }\end{array}$ & $\begin{array}{c}\text { Type of Cancer } \\
\text { Targeted }\end{array}$ \\
\hline $\begin{array}{c}\text { Bannister et al. } \\
\text { [105] }\end{array}$ & $\begin{array}{c}\text { Gold } \\
\text { NPs_Polyethylene } \\
\text { Glycol with Docetaxel }\end{array}$ & $\begin{array}{l}\text { Gold NPs of } 17.2 \mathrm{~nm} \text {, } \\
\text { gold nanoparticles of } \\
0.2 \mathrm{~nm} \text { along with } \\
50 \mathrm{~nm} \text { Docetaxel }\end{array}$ & Chemotherapy & $\begin{array}{l}\text { Docetaxel aided in } \\
\text { better retention of gold } \\
\text { NPs owing to } \\
\text { synchronism. } \\
\text { Enhanced therapeutic } \\
\text { effectiveness observed } \\
\text { with the complex }\end{array}$ & $\begin{array}{l}\text { Breast and } \\
\text { cervical cancer }\end{array}$ \\
\hline $\begin{array}{l}\text { Alamzadeh } \\
\text { et al. [106] }\end{array}$ & $\begin{array}{l}\text { Gold NPs with } \\
\text { alginate and cisplatin }\end{array}$ & $\begin{array}{c}20 \mu \mathrm{g} / \mathrm{mL} \text { gold } \\
\text { nanoparticle of } \\
44 \mathrm{~nm} \text { and cisplatin }\end{array}$ & $\begin{array}{l}\text { Chemotherapy } \\
\text { with } \\
\text { photothermal } \\
\text { therapy }\end{array}$ & $\begin{array}{l}\text { Therapeutic outcome } \\
\text { of the complex was } \\
\text { greatly improved with } \\
\text { the addition of } \\
\text { photothermal therapy. }\end{array}$ & Cervical cancer \\
\hline $\begin{array}{l}\text { Peng et al. } \\
\text { [107] }\end{array}$ & $\begin{array}{l}\text { Doxorubicin with gold } \\
\text { nanoparticles }\end{array}$ & $\begin{array}{l}\text { Gold NPs of } 2 \mathrm{~nm} \\
\text { size }\end{array}$ & Chemotherapy & $\begin{array}{l}\text { Higher anticancer } \\
\text { acitivity through } \\
\text { greater targeting } \\
\text { efficiency and } \\
\text { effectiveness. Better } \\
\text { renal clearance and } \\
\text { lower toxicity }\end{array}$ & Breast cancer \\
\hline $\begin{array}{l}\text { Safwat et al. } \\
\text { [108] }\end{array}$ & $\begin{array}{l}\text { 5- } \\
\text { Fluorouracil/Glutathione } \\
\text { gold nanoparticles }\end{array}$ & $\begin{array}{l}\text { Gold NPs of size } \\
\text { ranging between } \\
9 \text { and } 17 \mathrm{~nm}\end{array}$ & Chemotherapy & $\begin{array}{l}\text { Higher anticancer } \\
\text { activity reducing the } \\
\text { dose of the drug } \\
\text { required }\end{array}$ & Colorectal cancer \\
\hline $\begin{array}{l}\text { Kalimuthu } \\
\text { et al. [109] }\end{array}$ & $\begin{array}{l}\text { Peptide drug } \\
\text { conjugate with } \\
\text { chlorambucil- } \\
\text { Polyethylene Glycol } \\
\text { along with the gold } \\
\text { nanoparticles }\end{array}$ & $\begin{array}{l}\text { Gold NPs of size } \\
\text { ranging between } \\
25 \text { and } 50 \mathrm{~nm}\end{array}$ & Chemotherapy & $\begin{array}{c}\text { Longer duration of } \\
\text { action and better half } \\
\text { live of the anticancer } \\
\text { drug }\end{array}$ & Lymphoma \\
\hline
\end{tabular}

Another study was conducted involving in situ monitoring of the uptake of gold nanoparticles that were functionalized with alkaline thiol, which has a positive charge due to cancer cells attached to the surface. The monitoring was carried out with the aid of a high-throughput optical biosensor that used waveguide grating in resonance and had no label. The findings of the study indicated that positively charged particles with an ideal size of $5 \mathrm{~nm}$ penetrated target cells more effectively than negatively charged particles [110]. 


\section{Future Research Domains}

Based on our thorough and critical review on the applications of gold NPs for carcinoma therapy and biomedicinal applications, a number of research gaps were identified, thus enumerating domains for future research [111,112]. Due to the fact that cancer is responsible for millions of deaths each year, more preclinical and clinical trials using biogenic gold NPs should be performed, thus allowing us to understand their efficacy and safety in drug delivery [113]. Although substantial research indicates that gold NPs offer the lowest toxicity in comparison to other metallic NPs, toxicity studies of gold NPs are warranted because not much is known about the absorption, distribution, metabolism, and elimination (ADME) of these particles inside the body [114,115]. Furthermore, because there is a discrepancy between the in vitro and in vivo results obtained from utilizing gold NPs, there is significant capacity to explore this field and find a way to reconcile the findings of both types of studies. Although the development of nanomedicines clearly demonstrates substantial progress in the drug delivery field, it is also important to evaluate the extent to which the whole system of drug delivery may be properly modified to suit the selected drug. Proteins, peptides, and other small molecules have demonstrated great responsiveness when gold nanoparticles are selectively targeted to the damaged tissues. In the future, more in-depth studies on the subject should be conducted [116-119]. Due to the fact that gold NP synthesis is environmental friendly and produces minimum waste, future work may entail developing and functionalizing gold NPs into various sizes and shapes, followed by understanding the impact these particles have on the body [120,121]. With an improved knowledge about the molecular targeting in the field of biology, alternative ligands that can be used for the purpose of delivering specific anticancer drugs to particular sites, in addition to gold NPs, can be studied [122-125]. Moreover, research based on a thorough understanding of the pharmacokinetic profiles of gold nanoparticles should be encouraged, with a particular focus on gaining insights into the effects of ligand conjugation, nanoparticle size, and conjugation chemistry on the physiological properties of gold nanoparticles [126]. Another potential viewpoint that requires consideration is the cumulative effect of gold NPs' toxicity upon repeated exposure to the human body $[127,128]$.

\section{Conclusions}

Metallic NPs are at the forefront of oncotherapy due to several advantages. Gold NPs have been found to offer benefits such as targeted drug delivery, targeted heating, and radiation amplification. Chemical synthesis has been the focus of most efforts in this sector to obtain gold NPs. However, due to numerous limitations, the most serious being the usage of hazardous compounds, novel methods such as 'green synthesis', utilizing natural products such as plant extracts, fungus, yeast, or bacteria, have been explored. As most gold NPs have been shown to have a promising anti-tumor action in vitro, future research and conclusive data obtained from clinical trials will aid in establishing the efficacy and safety profiles of these particles, thereby enhancing patient/physician acceptability in oncotherapy.

Author Contributions: Conceptualization, T.B. and S.C.; methodology, T.B., D.D. and G.A.B.e.S.; software, T.B. and H.C.; data curation, P.C., Z.A., M.A.H. and G.A.B.e.S.; writing-original draft preparation, T.B., H.C., S.C. and D.D.; writing—review and editing, S.C. and T.B.; visualization, T.B.; supervision, S.C.; project administration, S.C. and M.A.H. All authors have read and agreed to the published version of the manuscript.

Funding: This research received no external funding.

Institutional Review Board Statement: Not applicable.

Informed Consent Statement: Not applicable.

Data Availability Statement: Not applicable.

Acknowledgments: All figures were created using Biorender.com, accessed on 15 February 2022. 
Conflicts of Interest: The authors declare no conflict of interest.

\section{References}

1. Khan, A.; Rashid, R.; Murtaza, G.; Zahra, A. Gold Nanoparticles: Synthesis and Applications in Drug Delivery. Trop. J. Pharm. Res. 2014, 13, 1169. [CrossRef]

2. Ullah, M.; Aoudjeghout, W.; Pimpie, C.; Pocard, M.; Mirshahi, M. Mitosis in Cancer Cell Increases Immune Resistance via High Expression of HLA-G and PD-L1. Cancers 2020, 12, 2661. [CrossRef] [PubMed]

3. Otto, T.; Sicinski, P. Cell cycle proteins as promising targets in cancer therapy. Nat. Rev. Cancer 2017, 17, 93-115. [CrossRef] [PubMed]

4. Karki, K.; Hedrick, E.; Kasiappan, R.; Jin, U.-H.; Safe, S. Piperlongumine Induces Reactive Oxygen Species (ROS)-Dependent Downregulation of Specificity Protein Transcription Factors. Cancer Prev. Res. 2017, 10, 467-477. [CrossRef] [PubMed]

5. Siegel, R.L.; Miller, K.D.; Jemal, A. Cancer Statistics, 2017. CA Cancer J. Clin. 2017, 67, 7-30. [CrossRef]

6. Siegel, R.L.; Miller, K.D.; Jemal, A. Cancer statistics, 2019. CA Cancer J. Clin. 2019, 69, 7-34. [CrossRef]

7. Ratiu, C.; Brocks, M.; Costea, T.; Moldovan, L.; Cavalu, S. PRGF-Modified Collagen Membranes for Guided Bone Regeneration: Spectroscopic, Microscopic and Nano-Mechanical Investigations. Appl. Sci. 2019, 9, 1035. [CrossRef]

8. Dekker, E.; Tanis, P.J.; Vleugels, J.L.A.; Kasi, P.M.; Wallace, M.B. Colorectal cancer. Lancet 2019, 394, 1467-1480. [CrossRef]

9. Ferlay, J.; Colombet, M.; Soerjomataram, I.; Mathers, C.; Parkin, D.M.; Piñeros, M.; Znaor, A.; Bray, F. Estimating the global cancer incidence and mortality in 2018: GLOBOCAN sources and methods. Int. J. Cancer 2019, 144, 1941-1953. [CrossRef]

10. Tangen, C.M.; Neuhouser, M.L.; Stanford, J.L. Prostate Cancer. In Schottenfeld and Fraumeni Cancer Epidemiology and Prevention, 4th ed.; Oxford University Press: Oxford, UK, 2017; pp. 997-1018. [CrossRef]

11. Pérez, L.M.; López, S.A.; Fajes, J.L.H.; Martín, L.C. Carcinoma hepatocelular. Med.—Programa Form. Médica Contin. Acreditado 2020, 13, 653-665. [CrossRef]

12. Bray, F.; Ferlay, J.; Soerjomataram, I.; Siegel, R.L.; Torre, L.A.; Jemal, A. Global cancer statistics 2018: GLOBOCAN estimates of incidence and mortality worldwide for 36 cancers in 185 countries. CA Cancer J. Clin. 2018, 68, 394-424, Erratum in 2020, 70, 313. [CrossRef] [PubMed]

13. Torre, L.A.; Islami, F.; Siegel, R.L.; Ward, E.M.; Jemal, A. Global Cancer in Women: Burden and Trends. Cancer Epidemiol. Biomark. Prev. 2017, 26, 444-457. [CrossRef] [PubMed]

14. Jain, S.; Hirst, D.G.; O'Sullivan, J.M. Gold nanoparticles as novel agents for cancer therapy. Br. J. Radiol. 2012, 85, 101-113. [CrossRef] [PubMed]

15. Perveen, K.; Husain, F.; Qais, F.; Khan, A.; Razak, S.; Afsar, T.; Alam, P.; Almajwal, A.; Abulmeaty, M. Microwave-Assisted Rapid Green Synthesis of Gold Nanoparticles Using Seed Extract of Trachyspermum ammi: ROS Mediated Biofilm Inhibition and Anticancer Activity. Biomolecules 2021, 11, 197. [CrossRef] [PubMed]

16. Bharadwaj, K.K.; Rabha, B.; Pati, S.; Sarkar, T.; Choudhury, B.K.; Barman, A.; Bhattacharjya, D.; Srivastava, A.; Baishya, D.; Edinur, H.A.; et al. Green Synthesis of Gold Nanoparticles Using Plant Extracts as Beneficial Prospect for Cancer Theranostics. Molecules 2021, 26, 6389. [CrossRef] [PubMed]

17. Wang, S.; Lu, G. Applications of Gold Nanoparticles in Cancer Imaging and Treatment. In Noble and Precious Metals—Properties, Nanoscale Effects and Applications; IntechOpen: London, UK, 2017. [CrossRef]

18. Elahi, N.; Kamali, M.; Baghersad, M.H. Recent biomedical applications of gold nanoparticles: A review. Talanta 2018, 184, 537-556. [CrossRef]

19. Fan, W.; Yung, B.; Huang, P.; Chen, X. Nanotechnology for Multimodal Synergistic Cancer Therapy. Chem. Rev. 2017, 117, 13566-13638. [CrossRef]

20. Luther, D.C.; Huang, R.; Jeon, T.; Zhang, X.; Lee, Y.-W.; Nagaraj, H.; Rotello, V.M. Delivery of drugs, proteins, and nucleic acids using inorganic nanoparticles. Adv. Drug Deliv. Rev. 2020, 156, 188-213. [CrossRef]

21. Huang, H.; Feng, W.; Chen, Y.; Shi, J. Inorganic nanoparticles in clinical trials and translations. Nano Today 2020, $35,100972$. [CrossRef]

22. Pugazhendhi, A.; Edison, T.N.J.I.; Karuppusamy, I.; Kathirvel, B. Inorganic nanoparticles: A potential cancer therapy for human welfare. Int. J. Pharm. 2018, 539, 104-111. [CrossRef]

23. Bouchaala, R.; Mercier, L.; Andreiuk, B.; Mély, Y.; Vandamme, T.; Anton, N.; Goetz, J.G.; Klymchenko, A.S. Integrity of lipid nanocarriers in bloodstream and tumor quantified by near-infrared ratiometric FRET imaging in living mice. J. Control. Release 2016, 236, 57-67. [CrossRef] [PubMed]

24. Yang, G.; Phua, S.Z.F.; Bindra, A.K.; Zhao, Y. Degradability and Clearance of Inorganic Nanoparticles for Biomedical Appli-cations. Adv. Mater. 2019, 31, 1805730. [CrossRef] [PubMed]

25. Yi, C.; Yang, Y.; Liu, B.; He, J.; Nie, Z. Polymer-guided assembly of inorganic nanoparticles. Chem. Soc. Rev. 2020, 49, 465-508. [CrossRef] [PubMed]

26. Henriksen-Lacey, M.; Carregal-Romero, S.; Liz-Marzán, L.M. Current challenges toward in vitro cellular validation of inor-ganic nanoparticles. Bioconjug. Chem. 2017, 28, 212-221. [CrossRef] [PubMed]

27. Wu, S.-H.; Mou, C.-Y.; Lin, H.-P. Synthesis of mesoporous silica nanoparticles. Chem. Soc. Rev. 2013, 42, 3862-3875. [CrossRef]

28. Desalegn, T.; Ravikumar, C.R.; Murthy, H.C.A. Eco-friendly synthesis of silver nanostructures using medicinal plant Vernonia amygdalina Del. leaf extract for multifunctional applications. Appl. Nanosci. 2021, 11, 535-551. [CrossRef] 
29. Ladj, R.; Bitar, A.; Eissa, M.; Mugnier, Y.; Le Dantec, R.; Fessi, H.; Elaissari, A. Individual inorganic nanoparticles: Preparation, functionalization and in vitro biomedical diagnostic applications. J. Mater. Chem. B 2013, 1, 1381-1396. [CrossRef]

30. Hussain, M.H.; Abu Bakar, N.F.; Mustapa, A.N.; Low, K.-F.; Othman, N.H.; Adam, F. Synthesis of Various Size Gold Nanoparticles by Chemical Reduction Method with Different Solvent Polarity. Nanoscale Res. Lett. 2020, 15, 140. [CrossRef]

31. Sathishkumar, M.; Pavagadhi, S.; Mahadevan, A.; Balasubramanian, R. Biosynthesis of gold nanoparticles and related cytotoxicity evaluation using A549 cells. Ecotoxicol. Environ. Saf. 2015, 114, 232-240. [CrossRef]

32. Cavalu, S.; Fritea, L.; Brocks, M.; Barbaro, K.; Murvai, G.; Costea, T.O.; Antoniac, I.; Verona, C.; Romani, M.; Latini, A.; et al. Novel Hybrid Composites Based on PVA/SeTiO 2 Nanoparticles and Natural Hydroxyapatite for Orthopedic Applications: Correlations between Structural, Morphological and Biocompatibility Properties. Materials 2020, 13, 2077. [CrossRef]

33. Murthy, H.C.A.; Desalegn, T.; Kassa, M.; Abebe, B.; Assefa, T. Synthesis of Green Copper Nanoparticles Using Medicinal Plant Hagenia abyssinica (Brace) JF. Gmel. Leaf Extract: Antimicrobial Properties. J. Nanomater. 2020, 2020, 3924081. [CrossRef]

34. Bhattacharya, T.; e Soares, G.A.B.; Chopra, H.; Rahman, M.; Hasan, Z.; Swain, S.S.; Cavalu, S. Applications of PhytoNanotechnology for the Treatment of Neurodegenerative Disorders. Materials 2022, 15, 804. [CrossRef] [PubMed]

35. Murthy, H.A.; Zeleke, T.D.; Tan, K.; Ghotekar, S.; Alam, M.W.; Balachandran, R.; Chan, K.-Y.; Sanaulla, P.; Kumar, M.A.; Ravikumar, C. Enhanced multifunctionality of $\mathrm{CuO}$ nanoparticles synthesized using aqueous leaf extract of Vernonia amygdalina plant. Results Chem. 2021, 3, 100141. [CrossRef]

36. Lee, Y.J.; Ahn, E.-Y.; Park, Y. Shape-dependent cytotoxicity and cellular uptake of gold nanoparticles synthesized using green tea extract. Nanoscale Res. Lett. 2019, 14, 129. [CrossRef]

37. Yan, H.; Lin, Y.; Wu, H.; Zhang, W.; Sun, Z.; Cheng, H.; Liu, W.; Wang, C.; Li, J.; Huang, X.; et al. Bottom-up precise synthesis of stable platinum dimers on graphene. Nat. Commun. 2017, 8, 1070. [CrossRef]

38. Fichtner, J.; Garlyyev, B.; Watzele, S.; El-Sayed, H.A.; Schwämmlein, J.N.; Li, W.J.; Maillard, F.M.; Dubau, L.; Michalička, J.; Macak, J.M.; et al. Top-Down Synthesis of Nanostructured Platinum-Lanthanide Alloy Oxygen Reduction Reaction Catalysts: Pt x Pr/C as an Example. ACS Appl. Mater. Interfaces 2019, 11, 5129-5135. [CrossRef]

39. Fu, X.; Cai, J.; Zhang, X.; Li, W.-D.; Ge, H.; Hu, Y. Top-down fabrication of shape-controlled, monodisperse nanoparticles for biomedical applications. Adv. Drug Deliv. Rev. 2018, 132, 169-187. [CrossRef]

40. Mackus, A.J.M.; Merkx, M.J.M.; Kessels, W.M.M. From the Bottom-Up: Toward Area-Selective Atomic Layer Deposition with High Selectivity. Chem. Mater. 2019, 31, 2-12. [CrossRef]

41. Kuppusamy, P.; Yusoff, M.M.; Maniam, G.P.; Govindan, N. Biosynthesis of metallic nanoparticles using plant derivatives and their new avenues in pharmacological applications-An updated report. Saudi Pharm. J. 2016, 24, 473-484. [CrossRef]

42. De Oliveira, P.F.M.; Torresi, R.M.; Emmerling, F.; Camargo, P.H.C. Challenges and opportunities in the bottom-up mechanochemical synthesis of noble metal nanoparticles. J. Mater. Chem. A 2020, 8, 16114. [CrossRef]

43. Zhang, J.; Chaker, M.; Ma, D. Pulsed laser ablation based synthesis of colloidal metal nanoparticles for catalytic applications J. Colloid Interface Sci. 2017, 489, 138-149. [CrossRef] [PubMed]

44. Lee, K.X.; Shameli, K.; Yew, Y.P.; Teow, S.-Y.; Jahangirian, H.; Rafiee-Moghaddam, R.; Webster, T.J. Recent Developments in the Facile Bio-Synthesis of Gold Nanoparticles (AuNPs) and Their Biomedical Applications. Int. J. Nanomed. 2020, 15, 275-300. [CrossRef] [PubMed]

45. Miere, F.; Vicas, S.I.; Timar, A.V.; Ganea, M.; Zdrinca, M.; Cavalu, S.; Fritea, L.; Vicas, L.; Muresan, M.; Pallag, A.; et al. Preparation and Characterization of Two Different Liposomal Formulations with Bioactive Natural Extract for Multiple Applications. Processes 2021, 9, 432. [CrossRef]

46. Noruzi, M. Biosynthesis of gold nanoparticles using plant extracts. Bioprocess Biosyst. Eng. 2015, 38, 1-14. [CrossRef] [PubMed]

47. Virkutyte, J.; Varma, R.S. Green synthesis of metal nanoparticles: Biodegradable polymers and enzymes in stabilization and surface functionalization. Chem. Sci. 2011, 2, 837-846. [CrossRef]

48. Sheny, D.; Mathew, J.; Philip, D. Phytosynthesis of Au, Ag and Au-Ag bimetallic nanoparticles using aqueous extract and dried leaf of Anacardium occidentale. Spectrochim. Acta Part A Mol. Biomol. Spectrosc. 2011, 79, 254-262. [CrossRef]

49. Khalil, A.T.; Ovais, M.; Iqbal, J.; Ali, A.; Ayaz, M.; Abbas, M.; Ahmad, I.; Devkota, H.P. Microbes-mediated synthesis strategies of metal nanoparticles and their potential role in cancer therapeutics. Semin. Cancer Biol. 2021. [CrossRef]

50. Heinemann, M.G.; Rosa, C.H.; Rosa, G.R.; Dias, D. Biogenic synthesis of gold and silver nanoparticles used in environmental applications: A review. Trends Environ. Anal. Chem. 2021, 30, e00129. [CrossRef]

51. Gardea-Torresdey, J.L.; Parsons, J.G.; Gomez, E.; Peralta-Videa, J.; Troiani, H.E.; Santiago, P.; Yacaman, M.J. Formation and Growth of Au Nanoparticles inside Live Alfalfa Plants. Nano Lett. 2002, 2, 397-401. [CrossRef]

52. Sreelakshmi, C.; Datta, K.K.R.; Yadav, J.S.; Reddy, B.V.S. Honey Derivatized Au and Ag Nanoparticles and Evaluation of Its Antimicrobial Activity. J. Nanosci. Nanotechnol. 2011, 11, 6995-7000. [CrossRef]

53. Lee, K.X.; Shameli, K.; Miyake, M.; Kuwano, N.; Khairudin, N.B.B.A.; Mohamad, S.E.B.; Yew, Y.P. Green Synthesis of Gold Nanoparticles Using Aqueous Extract ofGarcinia mangostanaFruit Peels. J. Nanomater. 2016, 2016, 1-7. [CrossRef]

54. León, E.R.; Rodríguez-Vázquez, B.E.; Martínez-Higuera, A.; Rodríguez-Beas, C.; Larios-Rodríguez, E.; Navarro, R.E.; LópezEsparza, R.; Iñiguez-Palomares, R.A. Synthesis of Gold Nanoparticles Using Mimosa tenuiflora Extract, Assessments of Cytotoxicity, Cellular Uptake, and Catalysis. Nanoscale Res. Lett. 2019, 14, 334. [CrossRef] [PubMed] 
55. Keijok, W.J.; Pereira, R.H.A.; Alvarez, L.A.C.; Prado, A.R.; da Silva, A.R.; Ribeiro, J.; De Oliveira, J.P.; Guimarães, M.C.C. Controlled biosynthesis of gold nanoparticles with Coffea arabica using factorial design. Sci. Rep. 2019, 9, 16019. [CrossRef] [PubMed]

56. Botteon, C.E.A.; Silva, L.B.; Ccana-Ccapatinta, G.V.; Silva, T.S.; Ambrosio, S.R.; Veneziani, R.C.S.; Bastos, J.K.; Marcato, P.D Biosynthesis and characterization of gold nanoparticles using Brazilian red propolis and evaluation of its antimicrobial and anticancer activities. Sci. Rep. 2021, 11, 1974. [CrossRef] [PubMed]

57. Doan, V.-D.; Thieu, A.T.; Nguyen, T.-D.; Nguyen, V.-C.; Cao, X.-T.; Nguyen, T.L.-H.; Le, V.T. Biosynthesis of Gold Nanoparticles Using Litsea cubeba Fruit Extract for Catalytic Reduction of 4-Nitrophenol. J. Nanomater. 2020, 2020, 1-10. [CrossRef]

58. Lee, S.Y.; Krishnamurthy, S.; Cho, C.-W.; Yun, Y.-S. Biosynthesis of Gold Nanoparticles Using Ocimum sanctum Extracts by Solvents with Different Polarity. ACS Sustain. Chem. Eng. 2016, 4, 2651-2659. [CrossRef]

59. Camas, M.; Celik, F.; Camas, A.S.; Ozalp, H.B. Biosynthesis of gold nanoparticles using marine bacteria and Box-Behnken design optimization. Part. Sci. Technol. 2019, 37, 31-38. [CrossRef]

60. Sztandera, K.; Gorzkiewicz, M.; Klajnert-Maculewicz, B. Gold Nanoparticles in Cancer Treatment. Mol. Pharm. 2018, 16, 1-23. [CrossRef]

61. Kohout, C.; Santi, C.; Polito, L. Anisotropic Gold Nanoparticles in Biomedical Applications. Int. J. Mol. Sci. 2018, 19, 3385. [CrossRef]

62. Viswanath, B.; Kim, S. Influence of Nanotoxicity on Human Health and Environment: The Alternative Strategies. Rev. Environ. Contam. Toxicol. 2016, 242, 61-104. [CrossRef]

63. Alizadeh, S.; Nazari, Z. A Review on Gold Nanoparticles Aggregation and Its Applications. J. Chem. Rev. 2020, 2, 228-242. [CrossRef]

64. González-Ballesteros, N.; Rodríguez-Argüelles, M.C.; Prado-López, S.; Lastra, M.; Grimaldi, M.; Cavazza, A.; Nasi, L.; Salviati, G.; Bigi, F. Macroalgae to nanoparticles: Study of Ulva lactuca L. role in biosynthesis of gold and silver nanoparticles and of their cytotoxicity on colon cancer cell lines. Mater. Sci. Eng. C 2019, 97, 498-509. [CrossRef] [PubMed]

65. Jamkhande, P.G.; Ghule, N.W.; Bamer, A.H.; Kalaskar, M.G. Metal nanoparticles synthesis: An overview on methods of preparation, advantages and disadvantages, and applications. J. Drug Deliv. Sci. Technol. 2019, 53, 101174. [CrossRef]

66. Li, B.; Lane, L.A. Probing the biological obstacles of nanomedicine with gold nanoparticles. Wiley Interdiscip. Rev. Nanomed. Nanobiotechnol. 2019, 11, e1542. [CrossRef] [PubMed]

67. Kong, F.-Y.; Zhang, J.-W.; Li, R.-F.; Wang, Z.-X.; Wang, W.-J.; Wang, W. Unique Roles of Gold Nanoparticles in Drug Delivery, Targeting and Imaging Applications. Molecules 2017, 22, 1445. [CrossRef]

68. Khoshnevisan, K.; Daneshpour, M.; Barkhi, M.; Gholami, M.; Samadian, H.; Maleki, H. The promising potentials of capped gold nanoparticles for drug delivery systems. J. Drug Target. 2018, 26, 525-532. [CrossRef]

69. Thambiraj, S.; Vijayalakshmi, R.; Shankaran, D.R. An effective strategy for development of docetaxel encapsulated gold nanoformulations for treatment of prostate cancer. Sci. Rep. 2021, 11, 2808. [CrossRef]

70. Vines, J.B.; Yoon, J.-H.; Ryu, N.-E.; Lim, D.-J.; Park, H. Gold Nanoparticles for Photothermal Cancer Therapy. Front. Chem. 2019, 7, 167. [CrossRef]

71. Xu, M.; Soliman, M.G.; Sun, X.; Pelaz, B.; Feliu, N.; Parak, W.J.; Liu, S. How Entanglement of Different Physicochemical Properties Complicates the Prediction of in Vitro and in Vivo Interactions of Gold Nanoparticles. ACS Nano 2018, 12, 10104-10113. [CrossRef]

72. Spyratou, E.; Makropoulou, M.; Efstathopoulos, E.P.; Georgakilas, A.G.; Sihver, L. Recent Advances in Cancer Therapy Based on Dual Mode Gold Nanoparticles. Cancers 2017, 9, 173. [CrossRef]

73. Qi, F.; Zhu, C.; Yin, L. Predicting breast cancer recurrence using data mining techniques. In Proceedings of the 2010 International Conference on Bioinformatics and Biomedical Technology, Chengdu, China, 16-18 April 2010; pp. 310-311. [CrossRef]

74. Torre, L.A.; Siegel, R.L.; Ward, E.M.; Jemal, A. Global Cancer Incidence and Mortality Rates and Trends-An Update. Cancer Epidemiol. Biomark. Prev. 2016, 25, 16-27. [CrossRef] [PubMed]

75. Topete, A.; Alatorre-Meda, M.; Iglesias, P.; Villar-Álvarez, E.; Barbosa, S.; Costoya, J.A.; Taboada, P.; Mosquera, V. Fluorescent Drug-Loaded, Polymeric-Based, Branched Gold Nanoshells for Localized Multimodal Therapy and Imaging of Tumoral Cells. ACS Nano 2014, 8, 2725-2738. [CrossRef] [PubMed]

76. Masse, F.; Desjardins, P.; Ouellette, M.; Couture, C.; Omar, M.M.; Pernet, V.; Guérin, S.; Boisselier, E. Synthesis of Ultrastable Gold Nanoparticles as a New Drug Delivery System. Molecules 2019, 24, 2929. [CrossRef] [PubMed]

77. Cavalu, S.; Antoniac, I.V.; Mohan, A.; Bodog, F.; Doicin, C.; Mates, I.; Ulmeanu, M.; Murzac, R.; Semenescu, A. Nanoparticles and Nanostructured Surface Fabrication for Innovative Cranial and Maxillofacial Surgery. Materials 2020, 13, 5391. [CrossRef]

78. Herraiz, C.; Calvo, F.; Pandya, P.; Cantelli, G.; Rodriguez-Hernandez, I.; Orgaz, J.; Kang, N.; Chu, T.; Sahai, E.; Sanz-Moreno, V. Reactivation of p53 by a Cytoskeletal Sensor to Control the Balance Between DNA Damage and Tumor Dissemination. J. Natl. Cancer Inst. 2016, 108, djv289. [CrossRef]

79. Liu, X.-Y.; Wang, J.-Q.; Ashby, C.R.; Zeng, L.; Fan, Y.-F.; Chen, Z.-S. Gold nanoparticles: Synthesis, physiochemical properties and therapeutic applications in cancer. Drug Discov. Today 2021, 26, 1284-1292. [CrossRef]

80. Mendes, R.; Pedrosa, P.; Lima, J.C.; Fernandes, A.R.; Baptista, P.V. Photothermal enhancement of chemotherapy in breast cancer by visible irradiation of Gold Nanoparticles. Sci. Rep. 2017, 7, 10872. [CrossRef]

81. Nejati, K.; Dadashpour, M.; Gharibi, T.; Mellatyar, H.; Akbarzadeh, A. Biomedical Applications of Functionalized Gold Nanoparticles: A Review. J. Clust. Sci. 2022, 33, 1-16. [CrossRef] 
82. Sathiyaraj, S.; Suriyakala, G.; Gandhi, A.D.; Babujanarthanam, R.; Almaary, K.S.; Chen, T.-W.; Kaviyarasu, K. Biosynthesis, characterization, and antibacterial activity of gold nanoparticles. J. Infect. Public Health 2021, 14, 1842-1847. [CrossRef]

83. Pernar, C.H.; Ebot, E.M.; Wilson, K.M.; Mucci, L.A. The Epidemiology of Prostate Cancer. Cold Spring Harb. Perspect. Med. 2018, 8, a030361. [CrossRef]

84. Li, N.; Zhao, P.; Astruc, D. Anisotropic gold nanoparticles: Synthesis, properties, applications, and toxicity. Angew. Chem.-Int. Ed. 2014, 53, 1756-1789. [CrossRef] [PubMed]

85. Luo, D.; Wang, X.; Zeng, S.; Ramamurthy, G.; Burda, C.; Basilion, J.P. Prostate-specific membrane antigen targeted gold nanoparticles for prostate cancer radiotherapy: Does size matter for targeted particles? Chem. Sci. 2019, 10, 8119-8128. [CrossRef] [PubMed]

86. Hema, S.; Thambiraj, S.; Shankaran, D.R. Nanoformulations for Targeted Drug Delivery to Prostate Cancer: An Overview. J. Nanosci. Nanotechnol. 2018, 18, 5171-5191. [CrossRef] [PubMed]

87. Venditti, I.; Fontana, L.; Fratoddi, I.; Battocchio, C.; Cametti, C.; Sennato, S.; Mura, F.; Sciubba, F.; Delfini, M.; Russo, M.V. Direct interaction of hydrophilic gold nanoparticles with dexamethasone drug: Loading and release study. J. Colloid Interface Sci. 2014, 418, 52-60. [CrossRef]

88. Yamada, M.; Foote, M.; Prow, T.W. Therapeutic gold, silver, and platinum nanoparticles. Wiley Interdiscip. Rev. Nanomed. Nanobiotechnol. 2015, 7, 428-445. [CrossRef]

89. Dykman, L.A.; Khlebtsov, N.G. Gold nanoparticles in chemo-, immuno-, and combined therapy: Review [Invited]. Biomed. Opt. Express 2019, 10, 3152-3182. [CrossRef]

90. Paciotti, G.F.; Zhao, J.; Cao, S.; Brodie, P.J.; Tamarkin, L.; Huhta, M.; Myer, L.D.; Friedman, J.; Kingston, D.G.I. Synthesis and Evaluation of Paclitaxel-Loaded Gold Nanoparticles for Tumor-Targeted Drug Delivery. Bioconjug. Chem. 2016, 27, $2646-2657$. [CrossRef]

91. Gharatape, A.; Salehi, R. Recent progress in theranostic applications of hybrid gold nanoparticles. Eur. J. Med. Chem. 2017, 138, 221-233. [CrossRef]

92. Colangelo, E.; Comenge, J.; Paramelle, D.; Volk, M.; Chen, Q.; Lévy, R. Characterizing Self-Assembled Monolayers on Gold Nanoparticles. Bioconjug. Chem. 2017, 28, 11-22. [CrossRef]

93. Panahi, Y.; Mohammadhosseini, M.; Nejati-Koshki, K.; Abadi, A.J.N.; Moafi, H.F.; Akbarzadeh, A.; Farshbaf, M. Preparation, Surface Properties, and Therapeutic Applications of Gold Nanoparticles in Biomedicine. Drug Res. 2017, 67, 77-87. [CrossRef]

94. Lee, C.-S.; Kim, H.; Yu, J.; Yu, S.H.; Ban, S.; Oh, S.; Jeong, D.; Im, J.; Baek, M.J.; Kim, T.H. Doxorubicin-loaded oligonucleotide conjugated gold nanoparticles: A promising in vivo drug delivery system for colorectal cancer therapy. Eur. J. Med. Chem. 2017, 142, 416-423. [CrossRef] [PubMed]

95. Ramalingam, V.; Varunkumar, K.; Ravikumar, V.; Rajaram, R. Target delivery of doxorubicin tethered with PVP stabilized gold nanoparticles for effective treatment of lung cancer. Sci. Rep. 2018, 8, 3815. [CrossRef] [PubMed]

96. Khutale, G.V.; Casey, A. Synthesis and characterization of a multifunctional gold-doxorubicin nanoparticle system for $\mathrm{pH}$ triggered intracellular anticancer drug release. Eur. J. Pharm. Biopharm. 2017, 119, 372-380. [CrossRef] [PubMed]

97. Yang, H.; Zhao, J.; Wu, C.; Ye, C.; Zou, D.; Wang, S. Facile synthesis of colloidal stable MoS2 nanoparticles for combined tumor therapy. Chem. Eng. J. 2018, 351, 548-558. [CrossRef]

98. Anselmo, A.C.; Mitragotri, S. Nanoparticles in the clinic: An update. Bioeng. Transl. Med. 2019, 4, e10143. [CrossRef]

99. Gerosa, C.; Crisponi, G.; Nurchi, V.M.; Saba, L.; Cappai, R.; Cau, F.; Faa, G.; Van Eyken, P.; Scartozzi, M.; Floris, G.; et al. Gold Nanoparticles: A New Golden Era in Oncology? Pharmaceuticals 2020, 13, 192. [CrossRef]

100. Jain, P.; El-Sayed, I.H.; El-Sayed, M.A. Au nanoparticles target cancer. Nano Today 2007, 2, 18-29. [CrossRef]

101. Shi, J.; Kantoff, P.W.; Wooster, R.; Farokhzad, O.C. Cancer nanomedicine: Progress, challenges and opportunities. Nat. Rev. Cancer 2017, 17, 20-37. [CrossRef]

102. Deng, J.; Yao, M.; Gao, C. Cytotoxicity of gold nanoparticles with different structures and surface-anchored chiral polymers. Acta Biomater. 2017, 53, 610-618. [CrossRef]

103. Yang, C.; Bromma, K.; Di Ciano-Oliveira, C.; Zafarana, G.; Van Prooijen, M.; Chithrani, D.B. Gold nanoparticle mediated combined cancer therapy. Cancer Nanotechnol. 2018, 9, 4. [CrossRef]

104. Sibuyi, N.R.S.; Moabelo, K.L.; Fadaka, A.O.; Meyer, S.; Onani, M.O.; Madiehe, A.M.; Meyer, M. Multifunctional Gold Nanoparticles for Improved Diagnostic and Therapeutic Applications: A Review. Nanoscale Res. Lett. 2021, 16, 174. [CrossRef] [PubMed]

105. Bannister, A.H.; Bromma, K.; Sung, W.; Monica, M.; Cicon, L.; Howard, P.; Chow, R.L.; Schuemann, J.; Chithrani, D.B. Modulation of nanoparticle uptake, intracellular distribution, and retention with docetaxel to enhance radiotherapy. Br. J. Radiol. 2020, 93, 20190742. [CrossRef] [PubMed]

106. Alamzadeh, Z.; Beik, J.; Mirrahimi, M.; Shakeri-Zadeh, A.; Ebrahimi, F.; Komeili, A.; Ghalandari, B.; Ghaznavi, H.; Kamrava, S.K.; Moustakis, C. Gold nanoparticles promote a multimodal synergistic cancer therapy strategy by co-delivery of thermo-chemo-radio therapy. Eur. J. Pharm. Sci. 2020, 145, 105235. [CrossRef]

107. Peng, C.; Xu, J.; Yu, M.; Ning, X.; Huang, Y.; Du, B.; Hernandez, E.; Kapur, P.; Hsieh, J.; Zheng, J. Tuning the In Vivo Transport of Anticancer Drugs Using Renal-Clearable Gold Nanoparticles. Angew. Chem. Int. Ed. 2019, 58, 8479-8483. [CrossRef] [PubMed]

108. Safwat, M.A.; Soliman, G.M.; Sayed, D.; Attia, M.A. Gold nanoparticles enhance 5-fluorouracil anticancer efficacy against colorectal cancer cells. Int. J. Pharm. 2016, 513, 648-658. [CrossRef] [PubMed] 
109. Kalimuthu, K.; Lubin, B.-C.; Bazylevich, A.; Gellerman, G.; Shpilberg, O.; Luboshits, G.; Firer, M.A. Gold nanoparticles stabilize peptide-drug-conjugates for sustained targeted drug delivery to cancer cells. J. Nanobiotechnol. 2018, 16, 34. [CrossRef]

110. Peter, B.; Lagzi, I.; Teraji, S.; Nakanishi, H.; Cervenak, L.; Zambo, D.; Deák, A.; Molnár, K.; Truszka, M.; Székács, I.; et al. Interaction of Positively Charged Gold Nanoparticles with Cancer Cells Monitored by an in Situ Label-Free Optical Biosensor and Transmission Electron Microscopy. ACS Appl. Mater. Interfaces 2018, 10, 26841-26850. [CrossRef]

111. Sonali; Viswanadh, M.K.; Singh, R.P.; Agrawal, P.; Mehata, A.K.; Pawde, D.M.; Narendra; Sonkar, R.; Muthu, M.S. Nanotheranostics: Emerging strategies for early diagnosis and therapy of brain cancer. Nanotheranostics 2018, 2, 70-86. [CrossRef]

112. Wolfram, J.; Ferrari, M. Clinical cancer nanomedicine. Nano Today 2019, 25, 85-98. [CrossRef]

113. Youn, Y.S.; Bae, Y.H. Perspectives on the past, present, and future of cancer nanomedicine. Adv. Drug Deliv. Rev. 2018, $130,3-11$. [CrossRef]

114. Singh, P.; Pandit, S.; Mokkapati, V.R.S.S.; Garg, A.; Ravikumar, V.; Mijakovic, I. Gold nanoparticles in diagnostics and ther-apeutics for human cancer. Int. J. Mol. Sci. 2018, 19, 1979. [CrossRef] [PubMed]

115. Cao-Milán, R.; Liz-Marzán, L.M. Gold nanoparticle conjugates: Recent advances toward clinical applications. Expert Opin. Drug Deliv. 2014, 11, 741-752. [CrossRef] [PubMed]

116. Cao, J. Laser Pulse Duration Optimization for Photothermal Therapy with Gold Nanostars. Int. J. Med. Phys. Clin. Eng. Radiat. Oncol. 2018, 7, 391-402. [CrossRef]

117. Haume, K.; Rosa, S.; Grellet, S.; Śmiałek, M.A.; Butterworth, K.T.; Solov'Yov, A.V.; Prise, K.M.; Golding, J.; Mason, N.J. Gold nanoparticles for cancer radiotherapy: A review. Cancer Nanotechnol. 2016, 7, 8. [CrossRef]

118. Rahimi-Moghaddam, F.; Sattarahmady, N.; Azarpira, N. Gold-Curcumin Nanostructure in Photothermal Therapy on Breast Cancer Cell Line: 650 and 808 nm Diode Lasers as Light Sources. J. Biomed. Phys. Eng. 2019, 9, 473-482. [CrossRef]

119. Oraevsky, A.A. Gold and silver nanoparticles as contrast agents for optoacoustic tomography. In Photoacoustic Imaging and Spectroscopy; Lihong, V., Wang, L.V., Eds.; CRC Press: Boca Raton, FL, USA, 2017. [CrossRef]

120. Gao, Q.; Zhang, J.; Gao, J.; Zhang, Z.; Zhu, H.; Wang, D. Gold Nanoparticles in Cancer Theranostics. Front. Bioeng. Biotechnol. 2021, 9, 647905. [CrossRef]

121. Taghizadeh, S.; Alimardani, V.; Roudbali, P.L.; Ghasemi, Y.; Kaviani, E. Gold nanoparticles application in liver cancer. Photodiagn. Photodyn. Ther. 2019, 25, 389-400. [CrossRef]

122. Anselmo, A.; Mitragotri, S. A Review of Clinical Translation of Inorganic Nanoparticles. AAPS J. 2015, 17, 1041-1054. [CrossRef]

123. Dai, Q.; Wilhelm, S.; Ding, D.; Syed, A.; Sindhwani, S.; Zhang, Y.; Chen, Y.Y.; MacMillan, P.; Chan, W.C.W. Quantifying the Ligand-Coated Nanoparticle Delivery to Cancer Cells in Solid Tumors. ACS Nano 2018, 12, 8423-8435. [CrossRef]

124. An, L.; Wang, Y.; Tian, Q.; Yang, S. Small Gold Nanorods: Recent Advances in Synthesis, Biological Imaging, and Cancer Therapy. Materials 2017, 10, 1372. [CrossRef]

125. Pedrosa, P.; Vinhas, R.; Fernandes, A.; Baptista, P.V. Gold nanotheranostics: Proof-of-concept or clinical tool? Nanomaterials 2015, 5, 1853-1879. [CrossRef] [PubMed]

126. Riviere, J.E.; Jaberi-Douraki, M.; Lillich, J.; Azizi, T.; Joo, H.; Choi, K.; Thakkar, R.; Monteiro-Riviere, N.A. Modeling gold nanoparticle biodistribution after arterial infusion into perfused tissue: Effects of surface coating, size and protein corona. Nanotoxicology 2018, 12, 1093-1112. [CrossRef] [PubMed]

127. Harmsen, S.; Wall, M.A.; Huang, R.; Kircher, M.F. Cancer imaging using surface-enhanced resonance Raman scattering nanoparticles. Nat. Protoc. 2017, 12, 1400-1414. [CrossRef] [PubMed]

128. Jia, Y.-P.; Ma, B.-Y.; Wei, X.-W.; Qian, Z.-Y. The in vitro and in vivo toxicity of gold nanoparticles. Chin. Chem. Lett. 2017, 28, 691-702. [CrossRef] 